\title{
PARAMETERS OF UNCERTAINTY AMONG QUANTITY SURVEYORS FOR HERITAGE CONSERVATION REFURBISHMENT PROJECTS: THE CASE STUDY APPROACH
}

\author{
Faridah Ismail, Nurul Afida Isnaini Janipha, Izatul Laili Jabar and Farah Nasiha Suhaili \\ Faculty of Architecture, Planning \& Surveying Universiti Teknologi MARA, Shah Alam, Malaysia
}

Corresponding author: farid346@salam.uitm.edu.my

\begin{abstract}
Previous studies revealed that heritage conservation refurbishment projects contain more technical and economic uncertainty than new builds projects. Without a proper investigation by an experienced specialist, these uncertainties will remain unknown until the refurbishment works are carried out. Hence, it is insufficient for the Quantity Surveying (QS) to prepare tender documents for conservation work merely using standard documents for new building works. The objectives of this paper are to determine parameters of uncertainty that influence QS's services and to analyze the mitigation approaches in managing these uncertainties. Three projects were chosen as the Case Study in which the data was collected through questionnaire surveys distributed to five main stakeholders of the project. After the questionnaire distributed among the main consultants of the project, the same set of parameters of uncertainty were then verified with QS on which of those eleven (11) parameters of uncertainty that influence the QS's service. Case study analysis and content analysis are used in the data analysis. The results conclude that out of eleven (11) parameters of uncertainty; only three influenced QSS service in this project: availability of information; availability of material; and sufficiency of time allocation during the investigation phase. This study is intended to shed light for the QS to get an insight on heritage conservation refurbishment works as a whole and understand the main characteristic of the project which is complexity and uncertainty.
\end{abstract}

Keywords: Uncertainty parameters; Heritage Conservation; Refurbishment; Stakeholders.

\section{INTRODUCTION}

Traditionally, a Quantity Surveyor's (QS) area of expertise focuses on building projects, civil engineering, building services and other construction-related projects. But nowadays, the marketability of QS has expanded throughout various industries; that includes the heritage conservation refurbishment, oil and gas, manufacturing, infrastructure, petrochemical, aeronautical, and much more. According to Lee \& Lim (2009), the booming demand for professional QS is due to changes in industry requirements. Nevertheless, the heritage conservation refurbishment work is also not a new area to the QS practitioner as well; it has become vital after Melaka and Penang were announced as one of World Heritage Site. With that, the awareness and demand for conservation of heritage buildings are thriving all over Malaysia.

Unlike new building projects, the heritage conservation projects are unique and distinctive individually. This is consistent with research conducted by Zolkafli, et al. (2012), in which they found out that conservation projects were unique and non-duplicate project which do not have the precedent case to study. Due to that, heritage conservation refurbishment projects can be considered an extremely expert activity. The existence of complexity and uncertainty elements throughout the process can disturb the traditional needs for price certainty, an identified date of delivery and accredited quality standards (Reyers \& Mansfield, 2001). 


\section{QUANTITY SURVEYING SERVICES IN HERITAGE CONSERVATION REFURBISHMENT PROJECT}

Heritage is very important to a society and even a country. It reflects the true identity of the country. Fielden (1998) highlighted that it is through historic buildings that give people sense of wonder and make people eager to know more about the culture and history behind it. Meanwhile in Malaysia, according to the Malaysia National Heritage Act 2005 (Act 645), conservation refers to "preservation, restoration, reconstruction, rehabilitation and adaptation or any combination thereof". Highfield (2000) cited in Zolkafli, et al., (2012) define conservation refurbishment as a part of a repair, extension, and restoration. Whereas Mansfield (2000) stated that the purpose of refurbishment is to gain more advantages or beneficial use of an existing building.

Nowadays, the QS job scope is not only restricted to building works only. Instead, it has expanded throughout the industries. Heritage conservation refurbishment work is one of the industries that require QS expertise. Hence, the QS functions in new building projects and QS functions in heritage conservation refurbishment projects will be identified and analyse to achieve the second objective of the study which is to determine the parameter of uncertainties that influence QS's services for heritage conservation projects.

According to Edwards \& Pottinger (2010), 'Surveyors are professionals whose expertise involves a range of skills relating to land and buildings'. In 1971, the Royal Institution Chartered Surveyors (RICS) published a report titled The Future Role of the Quantity Surveyor (QS), which defined the work of the QS as:

'... ensuring that the resources of the construction industry are utilised to the best advantage of society by providing, among other things, the financial management for projects and a cost consultancy service to the client and designer during the whole construction process.'

Ashworth and Hogg (2013) stated that the traditional role of QS is still practised on small to medium-sized projects. It can be described as a measure and value system. QS should prepare using a single price method of estimating, produce bills of quantities for tendering, measure the progress payments based on the work and prepare final account by the tender documentation. Principally, there are two divisions of services outlined by the Royal Institution of Surveyors Malaysia (RISM) as tabulated in Table 2.1, which are the basic services and additional services. The basic services rendered include the arrangement of cost plans and preliminary cost estimates, recommendation and arrangement of procurement, tendering and contractual procedures, tendering process, preparation and implementation of the formal contract, interim valuation of on- site works progress, financial statement and settlement of the final accounts.

Meanwhile, additional services includes preparation of feasibility studies, the projection of estimated project or development expenditure, assessment of contractors for prequalification tendering, comparative cost studies, project management, life cycle costing, pricing of bills of quantities, valuation or auditing of contractual claims for arbitration cases, auditing of contracts and application of the full scope of quantity surveying in privatization contracts.

Table 2.1: Basic services and supplementary services for Quantity Surveyor

\begin{tabular}{ll}
\multicolumn{1}{c}{ Basic Services } & \multicolumn{1}{c}{ Supplementary Services } \\
\hline $\begin{array}{l}\text { Preparation of cost plans and preliminary cost estimates } \\
\text { of the project }\end{array}$ & Preparation of feasibility studies \\
\hline $\begin{array}{l}\text { Advice on cost estimates concerning design } \\
\text { development }\end{array}$ & $\begin{array}{l}\text { Projection of estimated project or development } \\
\text { expenditure and anticipated income cash flows }\end{array}$ \\
\hline $\begin{array}{l}\text { Advice and arrangement on procurement, tendering } \\
\text { and contractual procedures }\end{array}$ & $\begin{array}{l}\text { Evaluation of contractors registered for } \\
\text { prequalification }\end{array}$ \\
\hline $\begin{array}{l}\text { Preparation of the Bill of Quantities or Specification } \\
\text { document }\end{array}$ & $\begin{array}{l}\text { Comparative cost studies on the economics of the } \\
\text { project during design stage }\end{array}$ \\
\hline Organise the calling of tenders & $\begin{array}{l}\text { Project management of construction project } \\
\text { Tender report }- \text { tender evaluation }\end{array}$ \\
\hline $\begin{array}{l}\text { Life-cycle costing and studies on economics of } \\
\text { alternative design }\end{array}$
\end{tabular}




\begin{tabular}{ll}
\hline Preparation and execution of the formal contract & $\begin{array}{l}\text { Pricing of Bills of Quantities or agreeing and } \\
\text { negotiating on Schedule of Rates }\end{array}$ \\
\hline $\begin{array}{l}\text { Interim valuation of works in progress on site for } \\
\text { purposes of interim payments }\end{array}$ & $\begin{array}{l}\text { Valuation or auditing of contractual claims for } \\
\text { arbitrations litigation cases }\end{array}$ \\
\hline $\begin{array}{l}\text { Preparation of financial statement on regular basis } \\
\text { during the construction period }\end{array}$ & $\begin{array}{l}\text { Valuation or verification of insurance claims for fire } \\
\text { damaged buildings }\end{array}$ \\
\hline Settlement of the final accounts of the project & $\begin{array}{l}\text { Contracts audit and their related budgets and } \\
\text { expenditure }\end{array}$ \\
\hline & $\begin{array}{l}\text { Application of the full scope of quantity surveying } \\
\text { services in Turnkey or Privatisation Contracts or } \\
\text { privatisation contracts }\end{array}$
\end{tabular}

Source: http://www.rism.org.my/quantity-surveying-division-qs

On the other hand, ICOMOS (1993) has also highlighted the technical skills as well as the conservation skills that a professional needs to acquire for conservation projects. This is because the heritage conservation refurbishment project encompasses more of technical and economic uncertainties than the new build project reflecting the possible works that need to be thoroughly investigated and executed. Thus, it is crucial to have an experienced team of consultant backed up with strong technical skills of heritage conservation refurbishment projects apart from the basic and supplementary skills of QS.

Among the technical services according to ICOMOS (1993) is generally, to analyse works then converting those analyses into a financial plan. Besides, the QS also need to prepare an approximate estimate of the project with the consideration of all relevant aspects such as materials, labour, sub-contractors and access. To do that, the QS will use the information provided by the architect/surveyor/engineers/conservator to produce an accurate specification as well as Bills of Quantities. The Bill of Quantities portrays the works' quality often by reference to Standards Measurement Method prepared for new construction. In this case, the QS should consider and adjust accordingly to suits the heritage conservation refurbishment projects.

Furthermore, the QS of a heritage conservation refurbishment project likes any other QS of new building projects, should be able to advise on the economic aspects of the project from the very beginning of the project up until forecasting the whole life cycle of the project. After analyzing all necessary aspect of the project, the QS should advise the most appropriate form of contract to be adopted in which will create the point of reference for the project. Next, the QS shall prepare the tender documents based on all the information gathered from all parties for the contractors to price. Subsequently, the QS will check all the tender submitted and advice on acceptance of the best contractor's submission. When the construction works commencing on site, the QS will then make a valuation of work done and prepare interim payments to the contractor as per what they claimed and finally when the project ended the QS will check and adjusts the final account.

Almost all of the services mentioned above apply to all types of construction work. What differentiates the services under conservation heritage refurbishment projects with the new building projects is the technical knowledge on the conservation projects itself in which it requires the high level of appreciation towards the heritage building and understanding the importance of conservation.

According to Lee \& Lim (2009), an inadequate grasp of the extent and nature of conservation building projects would only lead to an inappropriate approach and inaccurate estimates in which results to cost implication when the QS performs pricing work. To prepare an accurate project budget; therefore, the QS should understand and allow for a particular scope of conservation work. Feilden (2000) suggested that the QS requires to visualised to help him comprehend the time and scope of works. It is crucial that his preliminary budget is "man enough" to include the entire scope of the works. The QS must be able to describe the division of his estimate in straightforward terms and prepare a cash flow programme for the client.

Besides, the QS should possess the ability to advise on contract procedures with the concern of flexibility in case of unforeseen problems arising during implementation of the works which serve the requirements of the building. 
Foreseen risks should be noted so that the contractor can plan his work properly. The QS should avoid increases in cost and reduce reason for claims.

A QS should not merge with incompatible subcontracts and should support the craftsmen to contribute skill and competence and make provisions for conservators. The QS should understand the utilization of scaffolding and other fixed tools such as temporary roofs and structural supports together with its effect on planning the building operation and costs.

Besides, the QS should report on a monthly or quarterly basis to the client on the cost of the project in consideration of all the changes makes by the client, architect or others. This is to allow firm control of costs against budget and to verify work done. The QS should be exclusively accountable for control of costs and avoid unnecessary and unproductive overheads. Apart from all that, the QS should comply with the ICOMOS Guidelines Para 5, sections $\mathrm{d}, \mathrm{g}, \mathrm{h}, \mathrm{i}, \mathrm{j}, \mathrm{k}, \mathrm{l}, \mathrm{m}, \mathrm{n}$, in which outlined the responsibility of a QS in heritage conservation work. Among the obligation is to gather all relevant information related to the project and make a report to non-specialist readers. On top of that, the QS should acknowledge UNESCO as the governing body for heritage buildings and obey all Charters, regulations and guidelines outlined by them. Table 2.2 demonstrates the summary of QS's services in conservation projects.

Table 2.2: Quantity Surveyor's services in conservation projects

\begin{tabular}{ll}
\hline \multicolumn{1}{c}{ Technical Services } & \multicolumn{1}{c}{ Conservation Services } \\
\hline $\begin{array}{l}\text { Analyses what needs to be done then converting his } \\
\text { understanding into a budget }\end{array}$ & $\begin{array}{l}\text { Understand the time and total scope of the works, able } \\
\text { to describe the division of his estimate in simple terms } \\
\text { and prepare an independent cash flow for the client }\end{array}$ \\
\hline $\begin{array}{l}\text { Makes approximate estimates of the cost of the project } \\
\text { in consideration all relevant factors such as availability } \\
\text { of materials, labours, subcontractors, access and } \\
\text { "tender climate." }\end{array}$ & $\begin{array}{l}\text { Advise on contract procedures considering the } \\
\text { during implementation of the works and which serve } \\
\text { the requirement of the building }\end{array}$ \\
\hline $\begin{array}{l}\text { Refer to specifications and produce Bills of Quantities } \\
\text { which measure the amount of work to be done and } \\
\text { specify the quality of work often by reference to }\end{array}$ & $\begin{array}{l}\text { Understand the utilization of scaffolding and other } \\
\text { fixed tools, e.g. temporary roofs and structural supports } \\
\text { and its effect on programming the building operation } \\
\text { and costs. }\end{array}$ \\
construction. & Should not merge with incompatible subcontracts. \\
\hline Advises on the economic aspects of a project & $\begin{array}{l}\text { Encourage the craftsmen to contribute skill and } \\
\text { competency and make provisions for conservators }\end{array}$ \\
\hline $\begin{array}{l}\text { Advises on the most appropriate form of contract } \\
\text { Prepares tender documents based on drawings and } \\
\text { specifications. }\end{array}$ & $\begin{array}{l}\text { Report on monthly or quarterly basis to the client on the } \\
\text { cost of the project in consideration of all changes made } \\
\text { by client, architect or others. }\end{array}$ \\
\hline
\end{tabular}

Check tenders when received and advises on acceptance.

Prepares valuations for interim payments

Source: ICOMOS (2003)

\section{PARAMETERS OF UNCERTAINTY IN HERITAGE CONSERVATION REFURBISHMENT PROJECTS}

Woon \& Mui (2010) in their paper discover that QS in Malaysia is still at the preliminary stage in understanding and managing conservation works. The basis of such argument is the findings they managed to collect from surveys on the application of specific documents for conservation works such as the Historical Architecture Building Survey (HABS), dilapidation survey and reconnaissance survey reports. Zolkafli, et al., (2012) added that there are fewer specialists in the sense of knowledge about the conservation projects. They further argued that if more knowledgeable expertise and specialist consultant can lower the risks in the heritage conservation refurbishment 
project. Mansfield J. R. (2009) claimed that most clients of heritage conservation refurbishment work typically rely upon a team of professionals for a broad range of project-centred advice. The use of specialist design consultants, usually chartered architects and chartered building surveyors, can significantly enhance the management of risks and to ensure optimum performance.

Heritage conservation refurbishment project is a unique, distinctive and highly specialised project which involves work that cannot accurately predetermine regarding the extent, specification, duration or cost (Zolkafli et al., 2012; Reyers \& Mansfield, 2001). The existence of uncertainty factors in heritage conservation refurbishment can jeopardize the accuracy of price estimates, completion date and quality of workmanship. Thus, it is crucial for the project team to identify every possible uncertainty variables during the earliest phase of the project. Laufer (1991) revealed that research on uncertainty in construction emphasises the importance of incorporating uncertainty factors in project cost and time forecast. Therefore, the approach used in the measurement of uncertainty in the present study would be adopted from the empirical analysis done in Table 3.1. The variable would be categorised as 'Heritage conservation refurbishment uncertainty variables'.

Table 3.1: Empirical Research on Parameter of Uncertainties

\begin{tabular}{|c|c|c|c|c|c|c|c|c|c|}
\hline & $\begin{array}{l}\text { (Ali, } \\
\text { 2009) }\end{array}$ & $\begin{array}{c}\text { (Faniran } \\
\text { et. al., } \\
\text { 1994) }\end{array}$ & $\begin{array}{l}\text { (Ali } \\
\text { et.al. } \\
2007)\end{array}$ & $\begin{array}{c}\text { (Rahmat } \\
\text {, 1997) }\end{array}$ & $\begin{array}{l}\text { (Ali } \\
\text { et.al. } \\
\text { n.d.) }\end{array}$ & $\begin{array}{c}\text { (Laufer } \\
, 1991)\end{array}$ & $\begin{array}{c}\text { (Reyers } \\
\& \\
\text { Mansfiel } \\
\text { d, 2001) }\end{array}$ & $\begin{array}{c}\text { (Zolkafl } \\
\text { iet al., } \\
2012)\end{array}$ & $\begin{array}{c}\text { (Ramgopa } \\
1,2003)\end{array}$ \\
\hline Information & 1 & 1 & 1 & 1 & I & 1 & I & I & 1 \\
\hline Client & 1 & & 1 & 1 & 1 & & & I & \\
\hline Access & 1 & & 1 & 1 & & & & I & \\
\hline Labour & & 1 & & 1 & & 1 & & & \\
\hline Material & & & & 1 & & & & 1 & \\
\hline Experience & & 1 & & & & 1 & & & \\
\hline Consultants & & & & & 1 & & 1 & & 1 \\
\hline Weather & & 1 & & & & I & & & \\
\hline Storage & & & & 1 & & & & & \\
\hline Objectives & & & & & & I & & & I \\
\hline Time variance & & & I & & 1 & & & & \\
\hline
\end{tabular}

Through the literature review analysis of previous researchers, eleven (11) dominant uncertainty variables that are associated with heritage conservation refurbishment projects were identified. The variables are the availability of information (Ali, 2009; Faniran et.al., 1994; Ali et.al;., 2007; Rahmat, 1997; Ali et.al., n.d.; Laufer, 1991; Reyers \& Mansfield, 2001; Zolkafli et.al., 2012; Ramgopal, 2003), changes in design made by the client during construction (Ali, 2009; Ali et.al., 2007; Rahmat, 1997; Ali et.al., n.d.; Zolkafli et.al., 2012), ease of access to the building (Ali, 2009; Ali et.al., 2007; Rahmat, 1997; Zolkafli et.al., 2012), availability of skilled labour (Faniran et.al., 1994; Rahmat, 1997; Laufer, 1991), availability of material (Rahmat, 1997; Zolkafli et al 2012), knowledge and experience of the stakeholders(Faniran et al 1994; Laufer, 1994), consultants interdependence and communication (Ali et.al., n.d.; Reyers \& Mansfield, 2001; Ramgopal, 2003), the impact of weather on the project (Faniran et.al., 1994; Laufer, 1991), amount of space available for storage of material on site (Rahmat, 1997), understanding and acknowledgment of project goal and objectives (Laufer, 1991; Ramgopal, 2003) and sufficiency of time allocation (Ali et.al., 2007; Ali et.al., n.d.). These 11 parameters of uncertainty have been elaborated in the previous research (Suhaili and Ismail,2015). 


\section{RESEARCH METHODOLOGY}

The case study approach is chosen as the study design because it can become the basis of a thorough, holistic and in-depth exploration of the aspect of the research study. The research focuses on heritage building conservation. According to Jabatan Warisan Negara (2013), there are about 48 buildings that were announced as national heritage and another 176 buildings were announced as a heritage building in Malaysia. Out of those national heritages and building heritage, the only building that fell under the category of the religious building will be chosen as the case study for the research. The religious buildings specifically mosque was chosen due to its building typology and the uniqueness which possesses different background history and architectural influence from one to another.

Among the 25 identified religious heritage buildings, only three (3) projects are selected based on the type of procurement system similarity between the projects. The procurement system reflects the parties involved in the project as well as their job scope. At the beginning of the research, a preliminary survey via an informal discussion was conducted to gain a general view of the heritage conservation refurbishment works. The survey was needed due to insufficient information about QS's practices in this area. The panel of discussion is an experienced QS working with Jabatan Warisan Negara and has been involved in various conservation works in Malaysia. Case studies were then performed to observe the current practice of the study area. This is a very efficient method where the author can observe the current practices and gets access to information relating to the research needs. During the case study, it will enable the author to identify these:

- Current practices of heritage conservation refurbishment projects

- QS's functions and influence during the pre-construction phase of the heritage conservation refurbishment project.

For the main data collection, the questionnaire survey was conducted to determine the perceived relative importance of the parameters of complexity and uncertainty. Subsequently, the interview was performed to determine which of the parameters influence the QS service as well as the mitigation approaches. Finally, this study demonstrated the application through case studies. Through the interview with experienced QSs, a deeper insight on what are the job scopes of a QS in heritage conservation refurbishment works can also be acquired.

The interview schedule is divided into three sections as follow:

i. Section A: Respondent's Demographic

ii. Section B: QS's Services in Heritage Conservation Refurbishment Works

iii. Section C: Parameters of uncertainty in Heritage Conservation Refurbishment Works

The collected data was analyzed through case study analysis and content analysis. All the data analyzed and organized in tables, means, and standard variation. The data used to test which of the parameters of uncertainty are applicable in heritage conservation refurbishment projects in Malaysia, especially in mosque projects.

\section{RESULT AND DISCUSSION}

The senior QSs for all three case studies were interviewed to ensure reliability and maturity of the answers. As shown in Table 5.1, among the three QS, only two of them; QS case study A (QSA) and QS case study B (QSB) are registered with the Board of QS Malaysia (BQSM) while the QS for case study C (QSC) is yet to register with the BQSM. Nonetheless, QSC has the most experience (more than ten years) in both construction industry and heritage conservation refurbishment project compared to QSA and QSB. The number of heritage conservation refurbishment project involved is more than eleven projects while QSB and QSC have involved in less than five projects. 
Table 5.1: Demographic Of Respondents

\begin{tabular}{llll}
\hline Project/Questions & Case Study A & Case study B & Case study C \\
\hline Position & Senior QS & Senior QS & Senior QS \\
\hline $\begin{array}{l}\text { Registered Quantity } \\
\text { Surveyor }\end{array}$ & Yes & Yes & No \\
\hline $\begin{array}{l}\text { Experience in } \\
\text { Industry }\end{array}$ & $>5$ Years but <8 Years & $>3$ Years but <5 Years & $>10$ Years \\
\hline $\begin{array}{l}\text { Organisation's registration status } \\
\text { Experience in heritage } \\
\text { conservation }\end{array}$ & Partnership & Sole Proprietorship & Sole Proprietorship \\
\hline $\begin{array}{l}\text { No. of Heritage conservation } \\
\text { involved }\end{array}$ & $>3$ Years but <5 Years & $<3$ Years & $>10$ Years \\
\hline
\end{tabular}

In short, among the three QSs, QSC has the most experience and knowledge in heritage conservation refurbishment project compared to QSA and QSB.

\subsection{Quantity Surveyor's Services}

Table 5.2 demonstrates the QS's services practised by all three QSs in the project. QSC practised all ten (10) services as underlined by RISM and ICOMOS. Meanwhile, QSA performs all services except stating the works' quality concerning Standards and Codes of Practice for new construction. According to QSA, the task was performed by the architect with assistance from a qualified conservator. Similarly, QSB also performed all tasks underlined by the RISM and ICOMOS except for advice on the most suitable form of contract. This is because case study B is a government project and all government projects practice the standard PWD form of contract 203A.

Table 5.2: Quantity Surveyor's Services

\begin{tabular}{|c|c|c|c|}
\hline Questions & QSA & QSB & QSC \\
\hline $\begin{array}{l}\text { Analyses what need to be done then convert the understanding into } \\
\text { budget }\end{array}$ & Yes & Yes & Yes \\
\hline $\begin{array}{l}\text { Makes approximate estimates of the cost of the project in consideration } \\
\text { all relevant factors such as availability of materials, labours, } \\
\text { subcontractors, access and "tender climate." }\end{array}$ & Yes & Yes & Yes \\
\hline $\begin{array}{l}\text { Refer the specifications and produce Bill of Quantities which measures } \\
\text { the amount of work to be done }\end{array}$ & Yes & Yes & Yes \\
\hline $\begin{array}{l}\text { Describe the works' quality concerning the Standards and Codes of } \\
\text { Practice for new construction }\end{array}$ & $\begin{array}{r}\text { Not } \\
\text { applicable }\end{array}$ & Yes & Yes \\
\hline Recommend on financial aspects of the project & Yes & Yes & Yes \\
\hline Advises on the most appropriate form of contract & Yes & $\begin{array}{r}\text { Not } \\
\text { applicable }\end{array}$ & Yes \\
\hline Prepare tender documents based on drawings and specifications & Yes & Yes & Yes \\
\hline Checks and advice on acceptance of tenders received & Yes & Yes & Yes \\
\hline Prepares valuations for interim payments & Yes & Yes & Yes \\
\hline Prepares and checks the final account & Yes & Yes & Yes \\
\hline
\end{tabular}




\subsection{Parameters of Uncertainties That Influence QS Services}

Table 5.3 illustrates the parameters of uncertainty that influence the QS services. From the 11 parameters of uncertainty, only a few of them were identified to have the impact on the QS's services. The most influential parameter is the availability of information followed by the availability of material as well as the sufficiency of time allocation for investigation phase. Other parameters include changes in design made by the client during construction, availability of skilled labour, knowledge and experience of stakeholders, the impact of weather and lastly understanding and acknowledgement of project goal \& objectives.

Table 5.3: Parameters of Uncertainty That Influence QS Services

\begin{tabular}{lccc}
\hline & QSA & QSB & QSC \\
\hline Accessibility of information & $/$ & $/$ \\
\hline Changes in design made by client during construction & $/$ & & \\
\hline Easy access to the site & $/$ & $/$ \\
\hline Availability of skilled labour & & $/$ \\
\hline Availability of material & & $/$ \\
\hline Knowledge/experience of the stakeholders & $/$ & \\
\hline Consultants interdependence and communication & & \\
\hline Effect of weather on the project & & $/$ \\
\hline Space available for storage of material on site & $/$ & \\
\hline Understanding \& acknowledgement of project goal \& objectives & \\
\hline Time allocation during investigation phase & & \\
\hline
\end{tabular}

All the three QS agreed that availability of information is crucial for QS to execute their services. Among the information required as mentioned by QSB is "comprehensive background information about the heritage building, scope of works prepared, complete set of new construction drawings, standard building specifications, conservation specification, Dilapidation Report, Jabatan Warisan Negara guidelines as well as tagging and video recording." QSC added scale photographs as one of the essential information required. QSC further highlighted that it is good if the architect can provide detail drawings of each wall sections so that all unforeseen item can be identified and addressed accordingly. The findings are in line with Ali (2009); Reyers \& Mansfield (2001); Zolkafli, et al. (2012) which highlighted that the availability of design information is the major problem faced in most of conservation refurbishment project.

QSA and QSB share the same opinion that availability of material may also influence QS services. Depending on the degree of conservation and project goal and objective, the level of uncertainty increases as the degree of conservation increases. It resulted in how similar does the building needs to be reproduced back to its original state. Hence, the project team may need to find material that is no longer available in the current market. The finding is contradicted with Rahmat(1997) which stated that the availability of material is not a major concern in the majority of refurbishment projects, and it rarely affects the planning performance.

As mentioned by Ali, Rahmat, \& Noordin (2007) there were many errors found in the design documents if the designers complete it in a hurry due to time constraint which leads to poor performance of refurbishment projects in terms overestimated cost and time. Thus, regarding sufficiency of time allocation during the investigation phase, QSA and QSB agreed that this parameter affects their services the most compared to other settings.. Due to time constraint, both QSA and QSB faced problem throughout the process of preparing an accurate estimate and comprehensive bill of quantities. However, due to excellent communication and teamwork within the project team, they managed to produce an accurate estimate and complete bill of quantities. As mentioned by QSA, "time will always be the biggest barrier to any projects. Hence, an efficient time management is needed to be practised by everyone together with co-operation between team members so that the dateline can be met." On the other hand, QSC did not face any project uncertainty due to insufficient time because QSC possesses vast experience and knowledge in the heritage conservation refurbishment project. Besides, data from previous projects does help in making ease of the QS services.

Unlike QSB and QSC, design changes in design made by the client during construction affect QSA the most regarding project certainty. As stated by Ali (2009), changes in design made by the client during construction 
happened mainly due to the incompleteness of design information during the initial stage. Due to that, the client was not sure on what is needed, and as the construction commences on site, they might have a different opinion, hence, the design changes.

Additionally, QSC highlighted that knowledge and experience is one of the crucial parameters that contribute to project certainty. "A team of consultants should be appointed based on their knowledge and expertise as the heritage conservation refurbishment project requires a specific technical knowledge and experience handling the unforeseen circumstances." Without proper knowledge, a designer cannot foresee what the works required for every item in the project are and what item should be included in the specifications. QSC specifically mentioned that "the most important person that needs to have that technical knowledge and experience is the architect as they are the one who will prepare most of the documents, reports and drawings." Every information produced by the architect will be the basis of the conservation project. The finding is supported by Laufer (1991) that construction experience is one of the most influential factors that affect both effort and outcome of a project.

Other parameters such as availability of skilled labour, the impact of weather as well as understanding and acknowledgement of project goal \& objectives also affect the QS's services due to uncertainty. However, the level of uncertainty was not significant enough compared to the four parameters explained earlier. In a nutshell, from the 11 parameters of uncertainty identified in the literature review, only nine (9) of the parameters influenced the QS services as follows:

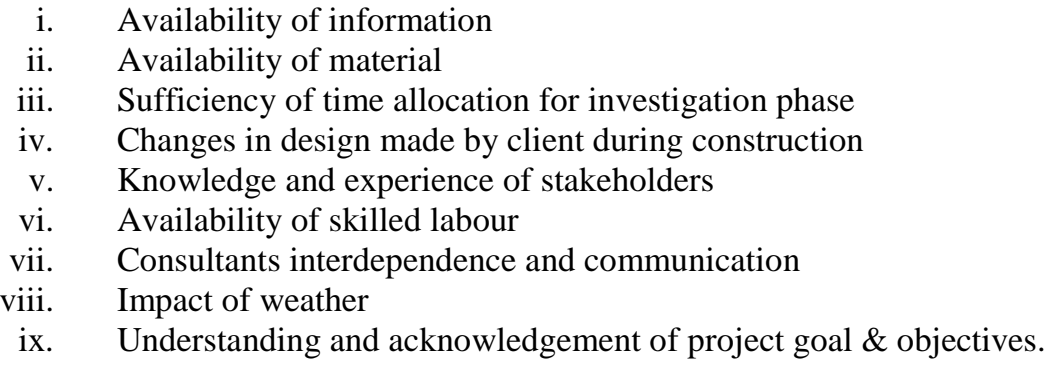

From the eleven (11) parameters of uncertainty derived (Suhaili and Ismail, 2015), these parameters were then clustered to seven (7) categories of uncertainty which are time, information, resources, experience, stakeholders, weather, accessibility and objectives. Based on the interview with QSA, QSB and QSC, six (6) categories parameters of uncertainty were highlighted which includes information, stakeholder, knowledge and experience, resources, weather and time. Table 5.4 summarizes the measures taken by all three QS in managing those uncertainties.

Table 5.4: Summary of the measures taken by all three QS in managing those uncertainties

\begin{tabular}{|c|c|c|c|}
\hline Uncertainty & QSA & QSB & QSC \\
\hline Information & $\begin{array}{l}\text { "To run a full study on } \\
\text { the original building } \\
\text { including all structural } \\
\text { works, architectural } \\
\text { works and also service } \\
\text { works. The study shall } \\
\text { cover in detail with input } \\
\text { from the end user." }\end{array}$ & $\begin{array}{l}\text { "Ensures that all information } \\
\text { (drawings and dilapidation report) } \\
\text { given by the architect, engineer } \\
\text { and conservator are } \\
\text { comprehensive." } \\
\text { "When in doubt, ask for } \\
\text { clarification and discuss with the } \\
\text { conservator and architect on what } \\
\text { are the suitable solution. } \\
\text { "To get as much information as } \\
\text { possible about the original } \\
\text { building from the owner of the } \\
\text { building." } \\
\text { "To confirm with Jabatan Warisan } \\
\text { Negara on the do's and don'ts for }\end{array}$ & $\begin{array}{l}\text { "Guide the designers on what is } \\
\text { needed for preparation of } \\
\text { estimates and tender document } \\
\text { since the QS possess the most } \\
\text { experience among the consultants." } \\
\text { "Participate actively in site } \\
\text { investigation so that all } \\
\text { information is synchronised } \\
\text { between designers and QS." } \\
\text { "Attend site meeting regularlyand } \\
\text { actively communicate with project } \\
\text { team using all media possible and } \\
\text { update any new information in } \\
\text { smartphone application; } \\
\text { WhatsApp." }\end{array}$ \\
\hline
\end{tabular}




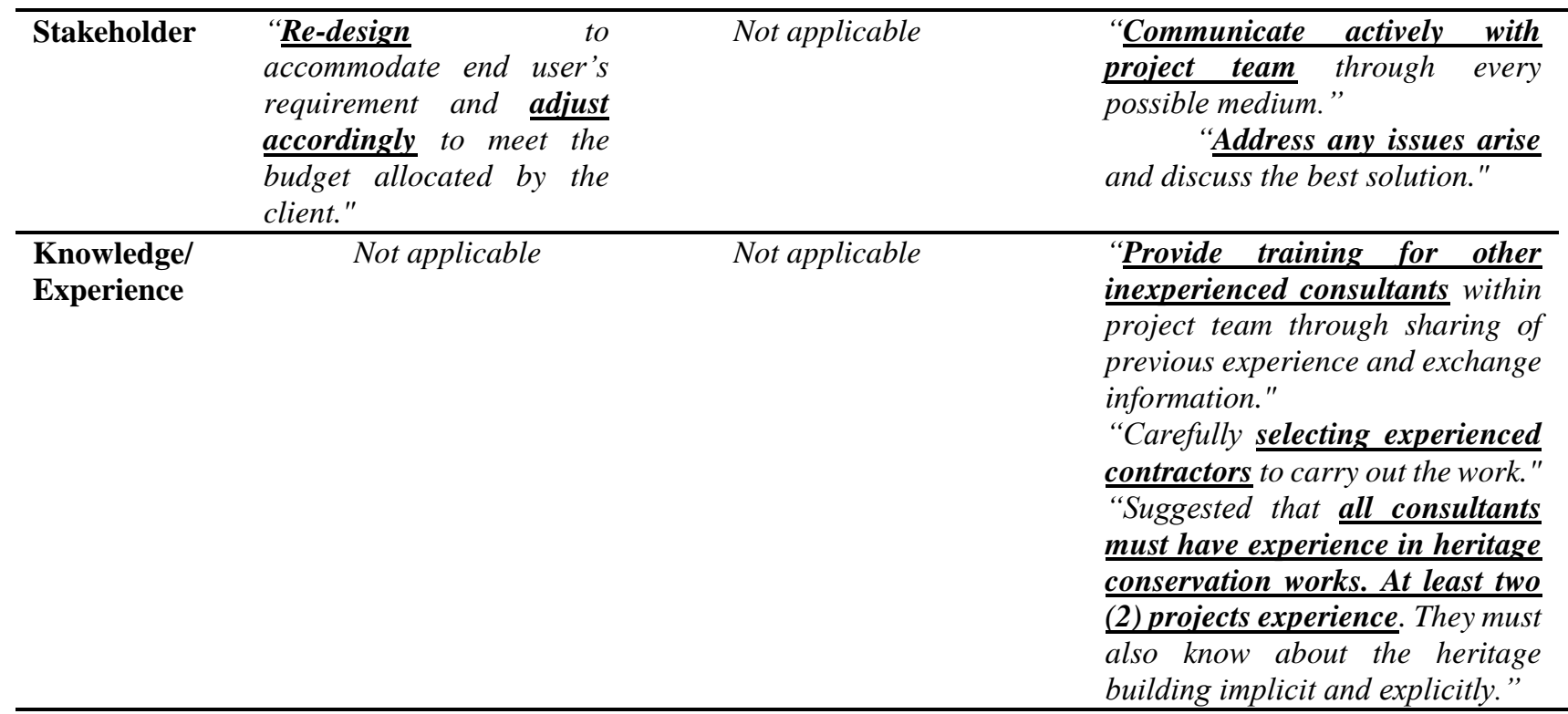

\section{Resources}

"For all special item, it will be deemed to be included under provisional sums in which is subject to remeasurement."
"All extra budget foresaw which mostly involve conservation scope of works was covered under provisional sum in which subject to re-measurement."

“Reliance on conservator's input is very high. All specification and advice on budget allocation were obtained from the conservator.

\begin{tabular}{|c|c|c|c|}
\hline Weather & $\begin{array}{l}\text { No mitigation approach } \\
\text { conducted }\end{array}$ & Not applicable & Not applicable \\
\hline Time & $\begin{array}{l}\text { "During preparation of } \\
\text { estimates and tender } \\
\text { document the time allocated } \\
\text { was limited, cost data from } \\
\text { the previous project helps in } \\
\text { allocation of budget for } \\
\text { individual items in the Bill of } \\
\text { Quantities }(B Q) "\end{array}$ & $\begin{array}{l}\text { No mitigation approach was } \\
\text { initiated. QSB follow the dateline } \\
\text { accordingly }\end{array}$ & $\begin{array}{l}\text { No mitigation approach was } \\
\text { initiated by QSC }\end{array}$ \\
\hline
\end{tabular}




\section{CONCLUSION}

The mosques conservation refurbishment projects are unique and distinctive individually. It involves works that cannot accurately predetermine regarding the extent, specification, duration or cost. To minimise the level of uncertainty in heritage conservation refurbishment projects, the parameters of uncertainty existed need to be identified and addressed accordingly. Throughout this study, the parameters of uncertainty were successfully identified. Based on an extensive literature review conducted, there are eleven (11) dominant parameters of uncertainties identified in heritage conservation refurbishment projects. The variables are the availability of information, changes in design made by the client during construction, ease of access to the building, availability of skilled labour, availability of material, knowledge and experience of the stakeholders, consultants interdependence and communication, the impact of weather on the project, amount of space available for storage of material on site, understanding and acknowledgment of project goal and objectives and sufficiency of time allocation. The 11 parameters of uncertainties were analysed individually and cross-tabulated among the case studies. It can be concluded that the parameters that contribute most to project uncertainty are the sufficiency of time $(12.77 \%)$, availability of information (11.17\%), consultant's knowledge and experience (10.64\%), availability of material $(10.90 \%)$ and availability of skilled labour (9.84\%).From the eleven (11) parameters of uncertainty identified, only nine (9) of the parameters influenced the QS's services. All nine (9) parameters were determined through a semistructured interview with the QSs of each case study. Only three influenced QSB's service in the chosen project: availability of information; availability of material; and sufficiency of time allocation during the investigation phase.

On the other hand, the mitigation approaches inferred that all the QS have already taken all necessary precaution to minimise uncertainties in the heritage conservation project. As a result, all three QS managed to produce an accurate estimate and comprehensive tender document as part of their services within the time frame and budget demanded by the client. This study is intended to shed light for the QS to get an insight into heritage conservation works as a whole and understand the main characteristic of the project which is complexity and uncertainty. To improve the services provided by the QS in the heritage conservation project, it is recommended that the QS should participate in the training to get some ideas on heritage conservation refurbishment works and explain in detail their responsibilities in the project. Meanwhile, as conservation works are slightly different from the new buildings works, the client is advised to select only experienced consultants and contractors for the project to ensure smooth and efficient operations.

\section{REFERENCES}

Ali, A. S. (2009). Complexity in Refurbishment of Services System for Historical Buildings in Malaysia. Kuala Lumpur: Faculty of Built Environment, University Malaya.

Ali, A. S., Rahmat, I., \& Hassan, H. (2008). Involvement of Key Design Participants in Refurbishment Design Process. Emerald Group, 389-400.

Ali, A. S., Rahmat, I., \& Noordin, N. (2007). The Design Process for Building Refurbishment Project. MIKRA 2007 (pp. B-8-1 - B-8-10). Shah Alam: Universiti Teknologi MARA.

Ali, A. S., Rahmat, I., \& Noordin, N. (n.d.). The Design Process for Building Refurbishment Projects. Unpublished PhD Thesis. Universiti Teknologi MARA, Shah Alam, Malaysia.

Ashworth, A., Hogg, K., \& Higgs, C. (2013). Willis's Practice and Procedure for the Quantity Surveyor. West Sussex: Wiley-Blackwell.

Edwards, G., \& Pottinger, G. (2012). Ethics in real estate practice: Education matters (No. eres2012-307). European Real Estate Society (ERES).

Faniran, O. O., Oluwoye, J. O., \& Lenard, D. (1994). Efficient Construction Planning. Construction Management and Economics, 485-499.

Feilden, B. (2000). Conservation of Historic Buildings. Oxford: Architectural Press. 
ICOMOS (1993). Guidelines On Education And Training In The Conservation Of Monuments, Ensembles And Sites. Colombo, Sri Lanka.

Laufer, A. (1991). Construction Planning in Uncertain Environments. Project Management, 53-60.

Lee, Q., \& Lim, Y. (2009). Preparation of Tender for Building Conservation Work: Current Practices in Malaysia. International Journal of Social, Management, Economics and Business Engineering, 81-86.

Mansfield, J. R. (2009). The use of formalised risk management approaches by UK design consultants in conservation refurbishment projects. Engineering, Construction and Architectural Management, 273-287.

Newton, S. (1985). Expert systems and the quantity surveyor. Surveyors.

Rahmat, I. (1997). The Planning and Control Process of Refurbishment Projects (Doctoral Dissertation). University of London.

Ramgopal, M. (2003). Project Uncertainty Management. Cost Engineering, 21-24.

Reyers, J., \& Mansfield, J. (2001). The Assessment of Risk in Conservation Refurbishment Projects. Structural Survey, 238-244.

Suhaili, F.N., Ismail, F. (2015) Identifying the Parameters of Uncertainty among Stakeholders for Heritage Conservation Refurbishment Projects: A Case Study of Mosques. $2^{\text {nd }}$ International Conference on Research Methodology for Built Environment and Engineering, Shah Alam, Malaysia, 7-8 October 2015.

Woon, W. L., \& Mui, L. Y. (2010). Elemental cost format for building conservation works in Malaysia. Emerald Insight, 408-419.

Zolkafli, U. K., Zakaria, N., Yahya, Z., Ali, A. S., Akashah, F. W., Othman, M., et al. (2012). Risks in Conservation Works. Journal Design + Built, 1-11. 